\title{
Investment Opportunities and Challenges in Tamil Nadu for Industrial Development- An
}

\section{Assessment}

\author{
Listin P T, D Ilangovan
}

\begin{abstract}
In recent years, significant of Foreign Direct Investment has been increasing especially in the developing countries. These countries are trying their level best to attract more and more FDI. Foreign Direct Investment takes place when a company invests directly in the production or marketing of a product in a foreign country.FDI is defined as an investment involving a long term relationship that reflects the long term interest and control of a resident entity in the host country. Industrial investment plays a significant role in the development of a country. Broadly there are two types of foreign investment viz., foreign direct investment and portfolio investment. The developments are easily possible through Foreign Direct Investment (FDI) because it helps to bring close the different economies of the world by investing capital in a country. Capital formation is an important determinant of economic growth. While domestic investments add to the capital stock in an economy, FDI plays a complementary role in overall capital formation and filling up the gap between domestic savings and investment. Foreign investment plays an important role in the long term economic development by augmenting availability of capital, enhancing competitiveness domestic economy through transfer of technology, strengthening infrastructure, raising productivity, generating new employment opportunities and boosting exports. The Government has implemented several reforms in recent years to attract more FDIs. These include improving infrastructure, revising the law on the land acquisition, reforming labour law and rationalizing the process of obtaining environmental clearances. In this article researcher focused on industrial opportunities and challenges in Tamil Nadu for industrial development of the state.
\end{abstract}

Keywords : Industry, FDI, Portfolio Investment, domestic investment.

\section{INTRODUCTION}

The economic liberalization that swept across the world, particularly since the late 1980s, was very significantly changed the environment for international investments. At the same time the surging international capital flows, in its turn are substantially impacting the business environment. Broadly there are two types of foreign investment, namely, foreign direct investment and portfolio investment.

Investment plays a significant role in the economic development of the country. Investment can be domestic as well as foreign investment. Gap between domestic savings and investment is being filled by foreign investment. So foreign

Revised Manuscript Received on September 25, 2019

Listin P T, Ph D Scholar, Department of commerce, Annamalai University, Tamil Nadu

Dr D Ilangovan, Professor and Head, Department of commerce, Annamalai University, Tamil Nadu investments complement economic growth and that ultimately lead to development in developing countries.

It plays an important role in the long term development of a country not only as a source of capital but also for enhancing competitiveness of the domestic economy through transfer of technology, strengthening infrastructure, raising productivity and generating new employment opportunities. The gap formed between intended investment and the actual savings of the country was lifted up by portfolio investments by foreign institutional investors, loans by foreign banks and other places, and foreign direct investments. Among these three forms of financial assistance, India prefers as well as possesses the maximum amount of Foreign Direct Investments.

Industry refers to the sector of economy which is related with manufacturing and production of different products. Industry is considered as a leading sector to economic development. Economies of scale can be assured by applying advanced technical knowhow, systematic management and division of labour. This results in increase of production, employment and simultaneous growth in capital formation and economic development.

Industrial sector will grow faster if there are skilled human resources sound economic and social infrastructures with organized banking sector for enabling the supply of financial facilities, good marketing facilities for the produced items, facilities of store houses to ensure supply in adequate times, competitiveness among the producers both in domestic and international market with the demand of the people.

Tamil Nadu continues to be a safe haven for the investors owing to ideal business climate and healthy socio economic reforms. At present, Tamil Nadu is in the vanguard of industrialization among Indian states and has become one of the most favoured investment destination in India. The state is ranked one of the top three states in terms of a number of parameters.

\section{Objectives}

The main objective of the study is to study the investment opportunities and

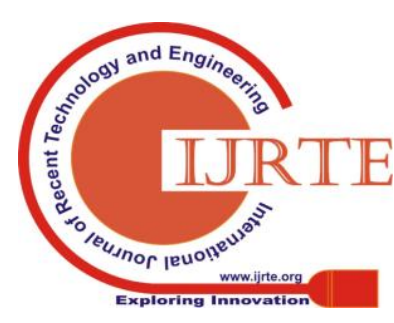


challenges in Tamil Nadu.

\section{RESEARCH METHODOLOGY}

This research paper is an attempt of exploratory research, based on the secondary data collected from journals, articles, media reports. Looking into the objectives of the study the research design employed for the study is descriptive research design. The research design was adopted to have greater accuracy and in depth analysis of the research study. Secondary data have comprehensively used for the study. Information from different articles, books, journals and websites are used which are recorded and enumerated.

\section{Investment Opportunities and Challenges}

In every economy one of the major sources of revenue is its industrial sector develops in accordance with the policy measures taken by the Government and the sophisticated infrastructure developed by the combined effort of the Government and the general public.

A good investment climate provides the opportunities and incentives for the firms to invest productively and create jobs, thus playing a key role in ensuring sustained growth and poverty reduction. Availability of use of factor inputs such as land and labour, availability of adequate physical and social infrastructure, such as power, telecom, urban infrastructure, water supply, hospitals and educational institutions. Governance and regulatory framework are the factors influencing investment climate. Tamil Nadu is one of the well developed states in the country in terms of industrial development.

Tamil Nadu has the following opportunities for competitiveness. Such as

\section{Fastest Growing Economy}

According to Department for Promotion of Industry and Internal Trade (DPIIT), cumulative FDI inflow in Tamil Nadu during April 2000 to March 2019 stood at US \$29.84billion. During 2017-2018 total merchandise exports from the state stood at US \$29.75bilion.

\section{Well Developed Infrastructure}

Infrastructure such as roads, effective transportation and registered carrier departure worldwide, information and communication technology, powers, financial institutions and legal system and other basic amenities which are must for the success of the business. The state is planning to attract investment in 12 sectors including automobile, textiles and renewable energy.In June 2018 Government invested Rs 5000 to boost renewable energy policies, transmission infrastructure and commission a floating solar plant.

\section{Mature Industrial Base}

Assist the existing industrial base to consolidate its gains and promote its efficient growth in the highly competitive domestic and export markets. Engender private public partnership and create an environment which enables the flow of substantial domestic and foreign capital for infrastructure building.

\section{Skilled Manpower}

A recent study found that in Tamil Nadu ITI graduates from only $12 \%$ of the labour force in the formal sector and $9 \%$ in the informal sector. There is abundant labour available in Tamil Nadu in terms of skilled and unskilled human resources.

\section{Economic Factors}

Different economic factors encourage inward FDI. These include interest of loans, tax, grants, subsidies and the removal of restrictions and limitation. The Union Government has given many tax exemption and subsidies to the foreign investors.

\section{Availability of Natural Resources}

If natural resources are available they can be used in production process or for extraction mines by the foreign investors.

Even though the situation is good for the industrial health of Tamil Nadu, it is not free from lacking. Major Challenges are given below;

\section{i. Political Instability.}

The coalition Government in order to keep in power has to tend the needs of the local government, thereby taking decisions unfavorable of Acts.

\section{ii. Poor Infrastructure}

India's infrastructure still continues to be one of the worst in the world. The power cuts remain to be a permanent challenge. The present infrastructures often do not get adequate Government support.

iii. Ever Changing Government Policies

Stable economic and policies have attracted investors across border. If the Government makes changes in policies which will affect the business. The business requires a lot of funds to be deployed and any change in policy against the investor will have a negative effect. Apparently India has one of the highest tariff rates; mounting corporate tax up to 35\%.Certain policy changes restrict the targeted FDI in the market.

\section{iv. Corruption and Bureaucracy}

In order to set up an operation in India, investors whether local or foreign have to pay bribery in some form or other. A mixture of legal backlogs, lack of institutional reforms, inefficient bureaucratic decision making and the allegations of corruption at the top have shied away a lot of foreign investors. 


\section{v. Stringent Labour Laws}

To retrench unnecessary workers firm require approval from both employees and State Government approval that is rarely given. Further, Trade Union extort huge sums from companies through overgenerous voluntary retirement schemes.

vi. High Corporate Tax Rates

Corporate tax rates are generally in the range of 15 to 30 percent, compared with a rate of 48 percent for foreign companies. High corporate tax is definitely a major disincentive to foreign corporate investment in the state.

\section{vii. Other Problems}

Other problems like regional imbalance, industrial sickness, defective licensing policies, unsatisfactory labour relations are adversely affect the industrial investment.

\section{FINDINGS}

Foreign Direct Investments helps in developing the economy by generating employment to the unemployed, generating revenues in the form of tax and incomes, financial stability to the Government, development of infrastructure, backward and forward linkage to the domestic firms for the requirements of raw materials, tools, business infrastructure and act as support for financial system. While attracting more FDI, it is mandatory to frame suitable policies that will promise overall development in Tamil Nadu which include growth of economic, social and human resources. The Government should formulate the policies which can attract more foreign investment in industrial sector rather than other sector, because FDI helps to meet the capital requirements and technological growth for industrial developments. Even though the situation is good for the industrial health of Tamil Nadu, it is not free from lacking. Insufficient power supply to the industries is utmost important problem of Tamil Nadu. In the modern scenario conventional energy will not be adequate for future projects. Government and public should fetch the alternate energy sources to overcome the crisis of this sector.

\section{CONCLUSION}

FDI plays a pivotal role in the economic and social development of the Tamil Nadu. In short it provides employment opportunities, boost the economy and in the long run, create an opportunity for the sustainable development of the state. So that there is need to have well chalked policy and strategies with the help of which more FDI can be attracted in Tamil Nadu. Development of infrastructure, especially power and transport network is an immediate need since it is basic for industrialization. Bureaucratic hassles, corruption and time consuming procedures should be reduced to attract more FDI inflow. After all more transparent investment system will benefit and secure future prospect of FDI in the state.

\section{REFERENCES}

1. Francis Cherunilam, Business Environment, Himalaya Publishing House,pp no. 600

2. Pallav Manik, Dr Sandeep Kumar, Growth and performance of FDI in India.

3. Anitha R, Foreign Direct Investment and Economic Growth in India, International Journal of Marketing, Vol.1,Issue8 2012,ISSN 2277 3622.

4. Dr C P SHaheed Ramzan and Hussain V, A Study on Problems and Prospects of Industrial Sector in Tamilnadu, An International Multidisciplinary Journal, Vol 3, Issue no 3, ISSN 2455-314X

5. www.ibef.org.

6. Tamil Nadu Global Investors Meet Agenda 2019 and www.ibef.org

7. Syed Azhar and K N Marimuthu, International Journal of Management Studies, Vol.2, Issue no 1,ISSN2249 8834.

8. Dr J N V Raghuram and Syed Shaaz, FDI Inflow- Trend Analysis, IJMET, Vol 8, Issue 12December2017, pp 10-20.

9. Syed Azhar and K N Marimuthu, International Journal of Management Studies, Vol.2, Issue no 1,ISSN2249 8834 